\title{
Ethanol extract of mangosteen (Garcinia mangostana Linn) peel effect in inhibiting the growth of human tongue cancer cells Supri's clone 1, invitro
}

\author{
Edi Suanto*), Roosje Rosita Oewen*, Inne Suherna Sasmita*, \\ Supriatno**, Unang Supratman*** \\ *Department of Pedodontics Faculty of Dentistry Universitas Padjadjaran, Bandung \\ **Department of Oral Disease Faculty of Dentistry Universitas Gajah Mada, Yogjakarta \\ ***Department of Chemistry Faculty of Mathematics and Natural Science Universitas Padjadjaran, \\ Bandung
}

\begin{abstract}
The incidence of tongue cancer in Indonesia reached $1.01 \%$ of all cancers and $42 \%$ of oral cavity cancer. Tongue cancer therapies including chemotherapy, radiotherapy, surgery, and all three combined therapy. Search for anti-cancer drugs currently switched on herbal plants, one of which is the mangosteen. Has the properties of mangosteen peel extract inhibited the growth of cancer cells. The purpose of the study, obtain $\mathrm{IC}_{50}$ of ethanol extract of mangosteen peel in inhibiting the growth of human tongue cancer cells SP-C1. Research carried out on 96 preparations of human tongue cancer SP-C1 were incubated with ethanol extract of mangosteen peel, preparations were classified in two groups of incubation time ( 24 hours and 48 hours) and each group will be given preferential treatment over 6 randomly different concentrations: 0 (control), $62.5 \mu \mathrm{g} / \mathrm{mL}, 125 \mu \mathrm{g} / \mathrm{mL}, 250 \mu \mathrm{g} / \mathrm{mL}, 500 \mu \mathrm{g} / \mathrm{mL}$ and $1000 \mu \mathrm{g} / \mathrm{mL}$. Model experiments were $2 \times 6$ factorial experiment with eight replication for each cell. Test results with ANAVA, incubation ( 24 and 48 hour) SP-tongue cancer cells with various concentrations of C1 ethanol extract of mangosteen peel gives a highly significant, indicating differences cancer cell growth inhibition. Incubation time factor showed the long incubation effect on cancer cell growth inhibition. Furthermore, by Newman Keuls test, showed $500 \mu \mathrm{g} / \mathrm{mL}$ concentrations of 24 -hour incubation had the best effect. Conclusion of the study of ethanol extract of mangosteen peel could achieve with $\mathrm{IC}_{50}$ values of cell growth resistance $50.3 \%$ at a concentration of $500 \mu \mathrm{g} / \mathrm{mL}$ and an incubation time of 24 hours.
\end{abstract}

Key words: Ethanol extract, Garciana mangostana Linn, Supri’s Clone 1 (SP-C1)

\section{ABSTRAK}

Insidensi kanker lidah di Indonesia mencapai 1,01\% dari seluruh jenis kanker dan 42\% dari kanker rongga mulut. Terapi kanker lidah meliputi kemoterapi, radioterapi, pembedahan, dan terapi gabungan ketiganya. Pencarian obat anti kanker saat ini beralih pada tanaman herbal, salah satunya adalah manggis. Ekstrak kulit manggis mempunyai sifat menghambat pertumbuhan sel kanker. Tujuan penelitian ini adalah untuk mendapatkan $I C_{50}$ dari ekstrak etanol kulit manggis dalam menghambat pertumbuhan sel kanker lidah manusia SP-C1. Penelitian dilakukan terhadap 96 sediaan kanker lidah manusia SP-C1

*)Correspondence author: Edi Suanto, Department of Pedodontic Faculty of Dentistry Universitas Padjadjaran

Jl. Sekeloa Selatan No. 1 Bandung, West Java-Indonesia, Tel./Fax: +6222-2504985/2532805 
yang diinkubasi dengan ekstrak etanol kulit manggis, sediaan dikelompokkan dalam 2 kelompok waktu inkubasi (24 jam dan $48 \mathrm{jam}$ ) dan tiap kelompok akan mendapatkan perlakuan secara acak atas 6 konsentrasi yang berbeda; 0 (kontrol); $62,5 \mu \mathrm{g} / \mathrm{mL} ; 125 \mu \mathrm{g} / \mathrm{mL} ; 250 \mu \mathrm{g} / \mathrm{mL} ; 500 \mu \mathrm{g} / \mathrm{mL}$; dan $1000 \mu \mathrm{g} / \mathrm{mL}$. Model eksperimen berbentuk eksperimen faktorial 2x6 dengan 8 replikasi untuk tiap sel. Hasil pengujian dengan ANAVA, inkubasi (24 dan 48 jam) sel kanker lidah SP-C1 dengan berbagai konsentrasi ekstrak etanol kulit manggis memberikan hasil yang sangat bermakna, yang menunjukkan adanya perbedaan hambatan pertumbuhan sel kanker. Faktor lama inkubasi berpengaruh terhadap hambatan pertumbuhan sel kanker. Selanjutnya, dengan uji Newman Keuls, konsentrasi $500 \mu \mathrm{g} / \mathrm{mL}$ dengan inkubasi 24 jam mempunyai efek yang paling baik. Simpulan penelitian ini adalah ekstrak etanol kulit manggis dapat mencapai $I C_{50}$ dengan nilai hambatan pertumbuhan sel sebesar $50,3 \%$ pada konsentrasi $500 \mu \mathrm{g} / \mathrm{mL}$ dan waktu inkubasi 24 jam.

Kata kunci: Ekstrak etanol, Garciana Mangostana Linn, Supri's Clone 1 (SP-C1)

\section{INTRODUCTION}

High incidency rate of tongue cancer accompanied by high mortality rate, mostly that is evolving in developing countries like Indonesia, is a problem that has to be solved. Different method of therapy, including surgery, radiation, chemotherapy, and/or the combination of those, have been applied to treat human tongue cancer. However, the incidence of tongue cancer has not yet decreased. ${ }^{1,2}$ In these past four decades, the exploration of herbal anti-cancer drugs have been invigorated with hope that herbal drugs have better effectiveness with lower side effects. ${ }^{3}$ Ethanol extract of mangosteen peels is one of the herbal material that is studied and it is believed to be efficacious as anti-inflammatory, anti-oxidant, anti-proliferation as well as apoptosis induction. ${ }^{4}$

The research of anti-cancer activity done by Elya ${ }^{5}$ and Matsumoto et al. ${ }^{6}$ was 6 Xanton (a, $B$, $Y$ mangostin, mangostinone, $E$ garcinone dan 2-isoprenyl-1,7-dihidroksi-3-metoksi Xanton) that was extracted from mangosteen peel, has a potency of inhibiting the proliferation of cancer cells as well as increasing the apoptosis process of cancer cells.

Research results showed that breast cancer cells proliferation was inhibited by the mangosteen peel extract, and the inhibition depends on the concentration. The mangosteen peel extract concentration of $6.25-25 \mu \mathrm{g} / \mathrm{ml}$ was effective to inhibit the cell proliferation. Therefore, mangosteen peel has been proved as a strong cell proliferation inhibitor towards breast cancer activity $\mathrm{IC}_{50}$ as much as $9.25 \pm 0.64 \mu \mathrm{g} / \mathrm{ml} .^{6}$ The most im- portant thing about the therapeutic effect finding from the extracted mangosteen peel with ethanol as the solvent was the finding of herbal material as proliferation inhibitor of cancer cells, including human tongue cancer Supri's Clone 1 (SP-C1). ${ }^{6,7}$

Materials used in this research include; Fetal bovain serum/FBS (Gibco, Australia), Fungizone liquid (Hyclone, Japan), Penicillinstreptomycin, erathanol extract of mangosteen peels (Tasikmalaya, Indonesia), Trypsin-EDTA (Gibco, Australia), MTT solution (Sigma Aldrich, USA), Isopropanol, Alcohol 70\%, PBS, and RPMI 1640.

Instruments used for this research are; Bio Rad microplate reader (Bio Rad, USA); Microplate 96 well (Iwaki, Japan); Adjustable volume digital pippetner (Eppendorf, Germany); Connical tube $15 \mathrm{ml}$ dan $50 \mathrm{ml}$ (Iwaki, Japan); Shaker (Lab Line, Japan); Waterbath (Eyela, Japan); Eppendorf mini tube (Iwaki, Japan); Incubator $37^{\circ} \mathrm{C}$; $\mathrm{CO}_{2} 5 \%$ (Sanyo, Japan); Refrigerator $4^{\circ} \mathrm{C},-20^{\circ} \mathrm{C}$, and $-30^{\circ} \mathrm{C}$ (Sanyo, Japan); electronic digital scale (Melter, Switzerland); Filter (Corming, Germany); Syringe $10 \mathrm{ml}$ (Terumo, Filipina); Vortex (Maxi mix II, USA); Clean bench (Sanyo, Japan); methylated spirit lamp; Flash (Iwaki, Japan); Petri dish (Iwaki, Japan); Microscope (Nikon, Japan); Suction (Assamica, Japan); and Haemocitometer (Assistant, Germany).

This research was conducted in Laboratorium Riset Terpadu (Research Centre Laboratory) Faculty of Dentistry Universitas Gadjahmada from April 2010 to October 2010, using the Supri's Clone 1 (SP-C1) tongue cancer cells. 


\section{METHODS}

The assessment of Supri's Clone 1 tongue cancer cells inhibition was done using microplate 96 well invitro. The research was conducted by counting the average proliferation of living SP-C1 tongue cancer cells after being incubated using various concentration of ethanol extract of mangosteen peels, with two groups of incubation time length, 24 and 48 hours. The results interpretation was completed using $450 \mathrm{~nm}$-wave length-Bio Rad microplate reader.

Ethanol extract of mangosteen peels was divided into 6 (six) test groups according to its concentration, as follow: First group was the control with 0 (zero) concentration of ethanol extract of mangosteen peels; Second group used $62.50 \mu \mathrm{g} / \mathrm{ml}$ concentrate of ethanol extract of mangosteen peels; Third group used the $125 \mu \mathrm{g} /$ $\mathrm{ml}$ concentrate; Fourth group used the $250 \mu \mathrm{g} /$

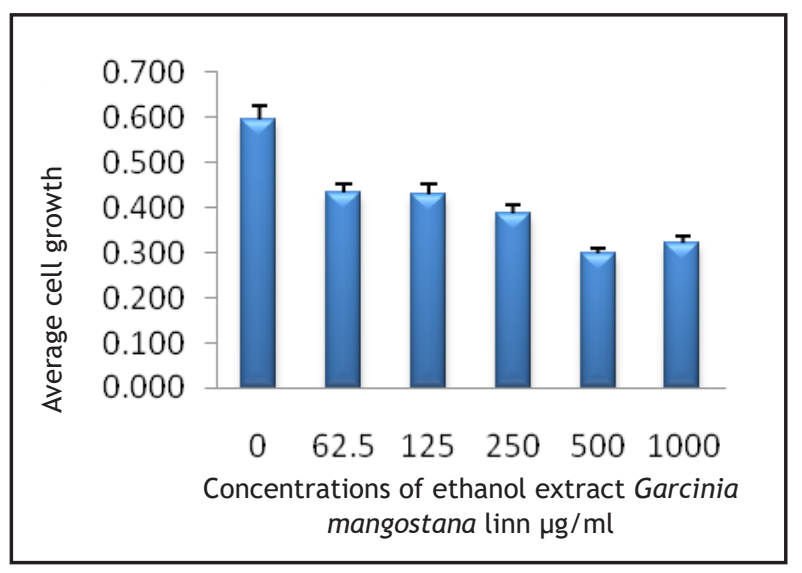

Figure 1. Average tongue cancer cell growth at incubation time 24 hours.

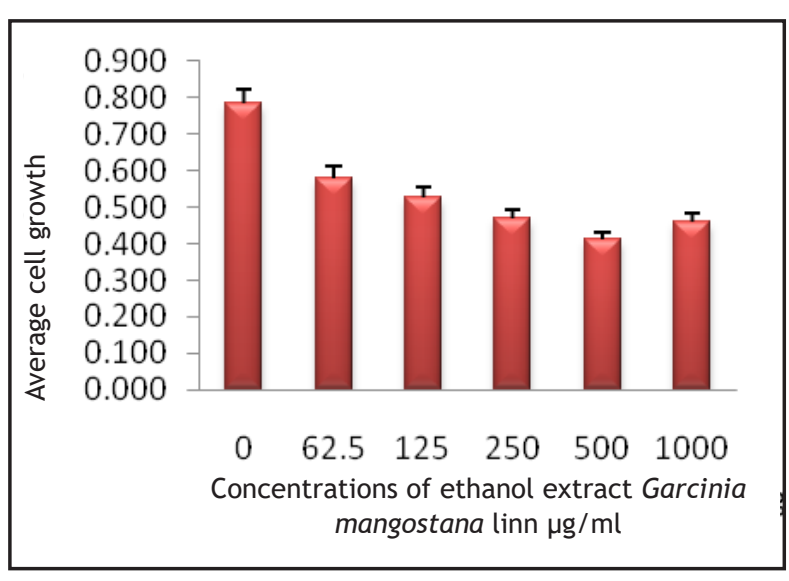

Figure 2. Average tongue cancer cell growth at incubation time 48 hours. m concentrate; Fifth group used the $500 \mu \mathrm{g} / \mathrm{ml}$ concentrate; and the sixth group used the 1000 $\mu \mathrm{g} / \mathrm{ml}$ concentrate.

The average of proliferation of SP-C1 tongue cancer cells was obtained using BioRad microplate reader. The cell viability percentage showed the interval number using the microplate 96 well filled with the Supri's Clone 1 (SP-C1) cancer cells cultures that was added various concentration of ethanol extract of mangosteen peels. The results were then examined with statistical analysis with ANOVA. If ANOVA were significant, Newman Keuls test was then performed.

\section{RESULTS}

Obtained from this study, the ethanol extract of mangosteen peel could inhibit tongue cancer cell growth of SP-C1 from the lowest concentration, $62.5 \mathrm{ug} / \mathrm{mL}$. In the Figure 1 showed that 0 (zero) concentrations was a control and showed an average growth of $100 \%$ of cells. Average reduction of the tongue cancer cell growth occurred from the concentration of the ethanol extract of mangosteen peel $62.5 \mu \mathrm{g} / \mathrm{mL}$ (mean, $72.3 \%$ cell growth). At a concentration of $125 \mu \mathrm{g} /$ $\mathrm{mL}$ (median 72 cells harbor-partum, 15\%) there was a slight increase, but at a concentration of 250 $\mu \mathrm{g} / \mathrm{mL}$ (mean $64.93 \%$ cell growth) the decreased were more, and the maximum peak decreased at a concentration of $500 \mu \mathrm{g} / \mathrm{mL}$ (median 49 cells harbor-partum, 66\%), whereas at a concentration of $1000 \mu \mathrm{g} / \mathrm{mL}$ (average growth of $53.69 \%$ of cells) a decline in average growth of cells smaller than $500 \mu \mathrm{g} / \mathrm{mL}$ concentration.

Figure 2 showed the average growth of tongue cancer cells after incubation with ethanol extract of mangosteen peel for 48 hours. The average growth of tongue cancer cells in zero concentrations after 48 hour of incubation was $100 \%$ and used as controls. Average reduction of cell growth started in the concentration of $62.5 \mu \mathrm{g} / \mathrm{mL}$ (mean of cell growth was $74.18 \%$ ) and continues to decrease with increasing concentrations of ethanol extract of mangosteen peel. Peak reduction was at a concentration of $500 \mu \mathrm{g} / \mathrm{mL}$ (mean cell growth, 52.34\%) while the concentration $1000 \mu \mathrm{g} /$ $\mathrm{mL}$ (mean cell growth, 58.52\%) occurs on average slightly increased cell growth compared to the concentration of $500 \mu \mathrm{g} / \mathrm{mL}$. 


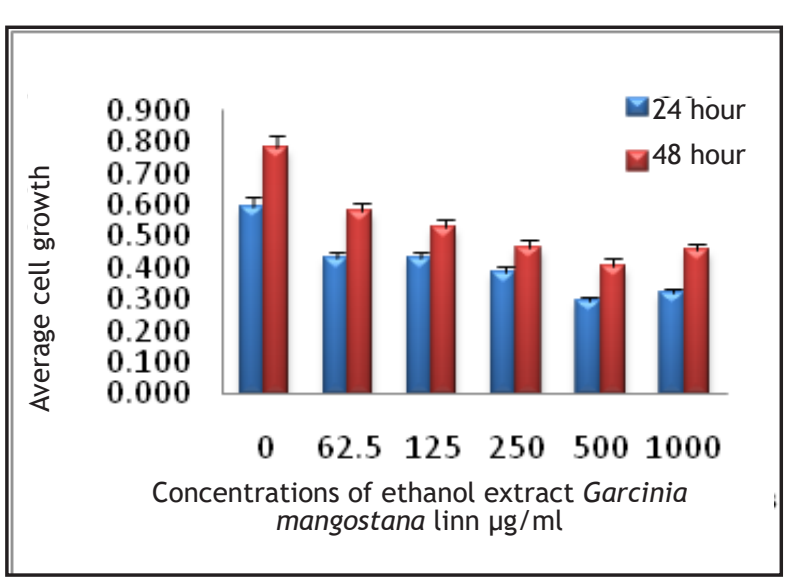

Figure 3. Comparison of average tongue cancer cells proliferation between 24-hour and 48-hour incubation periods

Figure 3 shows the comparison of SP-C1 tongue cancer cells between the 24 hour incubation and the 48 hour incubation within various concentration of ethanol extract of mangosteen peels. The average of cancer cells proliferation in both incubation time begans to decrease in the $62.5 \mu \mathrm{g} / \mathrm{ml}$ concentrate, and continuously decreased as the concentration of ethanol extract of mangosteen peels increases. The average cells proliferation peak was reached in the $500 \mu \mathrm{g} / \mathrm{ml}$ concentrate with 24 hours of incubation as much as $49.66 \%$, and as much as $52.34 \%$ in the 48 hours of incubation period. Therefore, the $500 \mu \mathrm{g} / \mathrm{ml}$ concentrate of ethanol extract of mangosteen peels was more effective to inhibit the average cells proliferation. The 24 -hour incubation period for the $500 \mu \mathrm{g} / \mathrm{ml}$ ethanol extract of mangosteen peels concentrate had the most effective inhibition cells proliferation score as much as $50.30 \%$. The average cells proliferation increased in 1000 $\mu \mathrm{g} / \mathrm{ml}$ concentrate with both the 24-hour-incubation period (cells proliferation average was $53.69 \%$ ) and the 48 -hour-incubation periods (cells proliferation average was $58.52 \%$ ).

Figure 4 shows the effect of ethanol extract of mangosteen peels towards the reduction of the average cancer cells growth as well as the inhibition of human tongue cancer cells proliferation with 24-hour and 48-hour incubation periods. It also shows that the most effective reduction of the average cancer cells growth and the maximum inhibition of cells proliferation occur in the 500 $\mu \mathrm{g} / \mathrm{ml}$ concentrate in both 24 -hour and 48 -hour incubation periods.

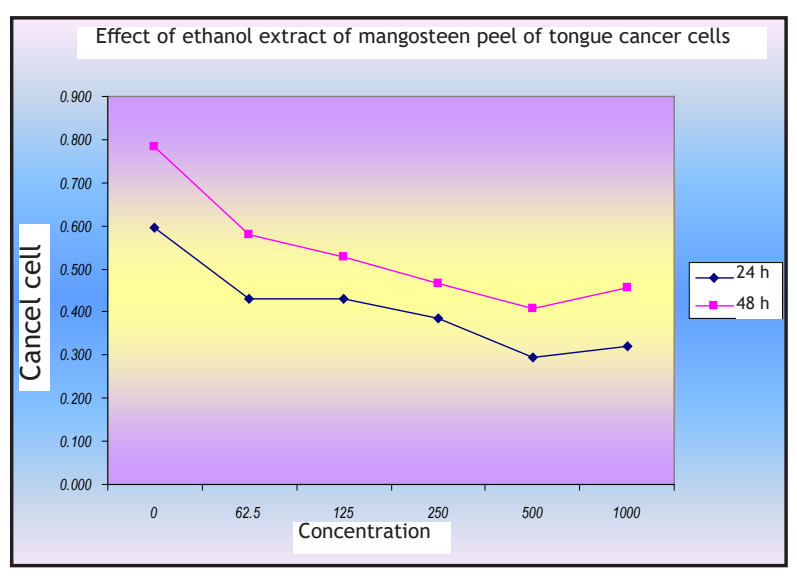

Figure 4. Average cancer cells proliferation in 24-hour and 48-hour incubation periods

\section{DISCUSSION}

There have been studies performed to analyze anticancer effect of Xanton isolated from mangosteen (Garcinia mangostana Linn.) peel, for instance towards the line hepatocellular cells ${ }^{6}$ towards SKBR3 human breast cancer ${ }^{8}$ and towards human leukemia. Ho et al. ${ }^{6}$ studied the cytotoxicity effect of 6 Xantons isolated from mangosteen peel and found out that $E$ garcinone has cytotoxicity effect towards the cell lines in liver cancer. ${ }^{6}$ Matsumoto et al. ${ }^{8}$ studied the effect of 6 Xantons ( $a, B$, dan $\gamma$ mangostin, mangostinon, garcinon $E$ dan 2-isoprenyl-1.7-dihidroxy-3-metoxy Xanton) isolated from mangosteen peel towards the leukemic cells HL60 inhibition. The result shows that all types of Xanton present significant inhibitory action, especially the $\alpha, B$, and $\gamma$ mangostin. ${ }^{6,9}$

Moongkarndi et al. assessed the cell proliferation inhibitory action, apoptosis, as well as antioxidant of the methanol extract of mangosteen peels using the breast cancer cell line SKBR3. The result showed that mangosteen peels has the most significant cell proliferation inhibitory effect $\left(E_{50}\right.$ $=9.25 \pm 0.64 \mu \mathrm{g} / \mathrm{ml}$ ) as well as inducts apoptosis process. ${ }^{6,10}$

Suksamrarn et al. isolated three new Xantons of the mangosteen peels, mangostenon C, D and $\mathrm{E}$, that were as beneficial as 16 other known Xantons. The cytotoxicity effect of these Xanton was tested on three different cancer cell lines; oral epidermoid carcinoma (KB), breast cancer (SM-1), and the lung cancer cell lines ( $\mathrm{NCl}-\mathrm{H} 187)$. Mangostenon $\mathrm{C}$ showed cytotoxic effects against 
all three cell lines with IC50 values respectively $2.8,3.53$, and $3.72 \mu \mathrm{g} / \mathrm{ml}$. The results of this study also show that a-mangostin has cytotoxic effects on oral epidermoid carcinoma cells (KB) $\left(\mathrm{IC}_{50}=2.08\right.$ $\mu \mathrm{g} / \mathrm{ml}){ }^{6}$

This study showed that ethanol extract of mangosteen peel achieves minimal inhibitory action $\left(\mathrm{IC}_{50}\right)$ in inhibiting the Supri's Clone 1 (SPC1) tongue cancer cells proliferation. The first graph showed an average growth of SP-C1 human tongue cancer after being incubated with various concentrations of ethanol extract of mangosteen peel $(0 /$ control, $62.5 \mu \mathrm{g} / \mathrm{ml}, 125 \mu \mathrm{g} / \mathrm{ml}, 250 \mu \mathrm{g} /$ $\mathrm{ml}, 500 \mu \mathrm{g} / \mathrm{ml}$, and $1000 \mu \mathrm{g} / \mathrm{ml}$ ) for 24 hours. Concentration of control was considered to have an average rate of cell growth by $100 \%$. The 62.5 $\mu \mathrm{g} / \mathrm{ml}$ concentrate had given decreasing effect of the average cell growth with the average value of cell proliferation by $72.3 \%$. It showe that the inhibitory action of the SP-C1 human tongue cancer cells after the 24-hour of incubation period had an inhibitory value of $27.68 \%$. In the concentration of $125 \mu \mathrm{g} / \mathrm{ml}$, the average cell growth decrease as much as $72.15 \%$ with the inhibitory value of $27.85 \%$. The $250 \mu \mathrm{g} / \mathrm{ml}$ concentrate presents greater average cell growth reduction as much as $64.93 \%$ which means the greater inhibitory value, as much as $35.07 \%$. The greater the concentration of ethanol extract of mangosteen peel, the greater tongue cancer cell growth inhibitory value produced.

At a concentration of $500 \mu \mathrm{g} / \mathrm{ml}$, the average cell growth decreased maximally with the rate of 49.66\%, and the cell growth inhibition showed the value of $50.3 \%$. It means that at a concentration of $500 \mu \mathrm{g} / \mathrm{ml}$ with 24-hour incubation period, the ethanol extract of mangosteen peel achieves IC50 with the cell growth inhibition value of $50.3 \%$. At the $1000 \mu \mathrm{g} / \mathrm{ml}$ concentrate, the value of average cell growth decreased, however the value was lower than the value at the $500 \mu \mathrm{g} / \mathrm{ml}$ concentrate, that was as much as $53.69 \%$ and the cell growth inhibition value was $46.3 \%$. From this result, we can conclude that at the concentration of $500 \mu \mathrm{g} / \mathrm{ml}$ the inhibition reaches its effective peak, however at higher concentration which is at the $1000 \mu \mathrm{g} / \mathrm{ml}$ concentrate, SP-C1 tongue cancer cells' receptors started to saturate. Therefore they cannot grasp the active molecule in the ethanol extract of mangosteen peel. Besides, at the higher the concentration of ethanol extract of mangosteen peel, collisions occured between higher active compounds molecules that were expected to stimulate cell growth.

Cell proliferation is a process of increasing the number of cells that involves the cell cycle. Normal cell cycle is strictly regulated by Cyclin, Cyclin Dependent Kinase (CDK) dan Cyclin Dependent Kinase Inhibitor (CKI) that work together continuously and jointly responsible for controlling the various phases of cell cycle control mechanisms in the check point..$^{1,2}$

In cancer cells, damage occurs to the basic regulatory mechanism of the cell behavior and the control of normal cell growth is impaired, resulting in uncontrolled cell growth. Ethanol extract of mangosteen peel affects as an inhibitor of SP-C1 tongue cancer cells growth by creating intervention in the cell cycle..$^{1,2}$

The result of previous research reports that the inhibition of cell cycle showed by a-mangostin and $\mathrm{B}$-mangostin inhibit the $\mathrm{G} 1$ phase, whereas the $S$ phase is inhibited by $\gamma$-mangostin. It is related to the modulation of expression of Cyclin, CDK2, and p27 in human colon cancer cells DLD-1. Moreover, a-mangostin increases the microRNA-143 level that negatively regulates Erk5 in translation phase as well as increases the inhibitory activity while the supplementary therapy using 5 -fluorouracil. ${ }^{6}$

The inhibition of SP-C1 human tongue cancer cells growth by the ethanol extract of mangosteen peel occurs between $\mathrm{G} 1$ to $S$ and between phase $S$ to $\mathrm{G} 2$, by inhibiting the signal from $\mathrm{CMyc}$ so that the sinthesis between Cyclin D and CDK4/6 occurs and lead to the phosphorilation of $\mathrm{Rb}$ protein binding with E2F. It results in separation of E2F so that E2F is able to activate the beginning of cell cycle in phase $\mathrm{G} 1$ to pass through the restriction point and start the cell proliferation process. ${ }^{4,11}$

The inhibitory of cell growth also occurs at phase $S$ by inhibiting the signal from $C M y c$ within synthesis between Cyclin E and CDK 2 that results in phosphorilating protein binding of $\mathrm{Rb}$ and E2F. The phosphorilation results in separation of $\mathrm{Rb}$ and E2F and lead to activation of cell cycle to continue to the next phase of the cell cycle. Thus, ethanol extract of mangosteen peel plays role in inhibiting the signal between $\mathrm{CMyc}$ towards Cyclin D with CDK 4/6, as well as between Cyclin E with CDK2 so that the growth signal could not cause 
phosphorilation of protein $\mathrm{Rb}$ and E2F binding, and the cell cycle cannot be activated. ${ }^{6,11}$.

\section{CONCLUSION}

Ethanol extract of mangosteen peel accomplishes its minimum inhibition $\left(\mathrm{IC}_{50}\right)$ in inhibiting Supri's Clone 1 (SP-C1) human tongue cancer cells proliferation in vitro with the inhibitory value of $50.3 \%$ at the concentration of $500 \mu \mathrm{g} / \mathrm{ml}$. Minimum inhibition of cancer cell proliferation $\left(\mathrm{IC}_{50}\right)$ of ethanol extract of mangosteen peel was accomplished in the 24-hour incubation period.

\section{REFERENCES}

1. Kumar V, Abbas AK, Fausto N, Robbin SL, Cotran RZ. Robbin and Cotran basic pathology. Philadelphia: Saunders; 2007.

2. Desen W. Buku ajar onkologi klinis. Jakarta: Balai Penerbit FKUI; 2008.

3. DK. Kanker rongga mulut, awalnya seperti sariawan. Jakarta: PDGI Online; 2008.

4. Chen LG, Yang L. Wang C. antiinflammatory activity of mangostins from Garcinia mangostana. Food and Chemical Toxicology 2007

5. Elya B. Manfaat kulit manggis: antikanker \& antioksidan kuat. Jakarta: Departemen
Farmasi Universitas Indonesia; 2009.

6. Chaverri JP, Rodriguez NC, Ibarra MO, Jasmin $M$, Rojas P. Medicinal properties of Mangosteen (Gracinia mangostana). Mexico: Elsevier; 2008.

7. Supriatno. Oligonukleotid S-phase kinase associated protein-2(SKP) antitense menginduksi hambatan proliferasi dan peningkatan aktivitas apoptosis pada sel kanker dan kepala. Yogyakarta: UGM; 2007

8. Jung et al. Antioxidant xanthones from the pericarp of Garcinia Mangostana (Mangosten). Ohio: Nature Sunshine Product. Inc.; 2006.

9. Chin YW. Kinghorn AD. Structural characterization, biological effects, and synthetic studies on Xanthones from Mangosteen (Garcinia mangostana), a popular botanical dietary supplement. USA: The Ohio State University; 2008.

10. Paramawati R. Dahsyatnya manggis untuk menumpas penyakit. Jakarta: Agromedia; 2010.

11. Tan Y. Cell cycling technology: inovatif discovery for signal transduction research; 2004.

12. Osman M, Milan AR. Mangosteen Garcinia Mangostana L. Chichester (UK): Southampton Centre of Underutilized Corps.; 2006 